\title{
Studi Evaluatif Profesionalisme Guru Lulusan S1 PGSD dalam Keterampilan Menulis
}

\author{
Loliyana, Fitria Akhyar \\ Pendidikan Guru Sekolah Dasar, Universitas Lampung \\ Jl. Prof. Dr. Soemantri Brojonegoro No. 1 Bandar Lampung, Indonesia \\ E-mail: loli.yana@fkip.unila.ac.id
}

\begin{tabular}{l} 
Article Info \\
\hline Received Desember 2019 \\
Accepted Februari 2020 \\
Published April 2020
\end{tabular}

Keywords:

Writing skills, teacher.

\begin{abstract}
The teacher must be able to present good language ethical learning. It considers that the teacher is not only a source of learning material but also as a role model for students. Therefore, this study was conducted to describe the teacher's writing skills. This study used a descriptive analytic approach using a questionnaire and portfolio documentation. The research sample consisted of 26 teachers in Bandar Lampung. Based on research data, the average value of writing skills was 74.12. Thus, it can be concluded that the language skills of elementary school teachers in Bandar Lampung City are categorized as good.
\end{abstract}

\begin{abstract}
Abstrak : Guru harus mampu menyuguhkan pembelajaran yang beretika bahasa yang baik. Ini mempertimbangkan bahwa guru tidak hanya sebagai sumber materi pembelajaran tetapi juga sebagai role model bagi siswa. Oleh karena itu, penelitian ini dilakukan untuk mendeskripsikan keterampilan menulis guru. Penelitian ini menggunakan pendekatan deskriptif analitik dengan menggunakan angket dan dokumentasi portofolio. Sampel penelitian berjumlah 26 orang guru di Bandar Lampung. Berdasarkan data hasil penelitian, didapatkan nilai rata-rata keterampilan menulisnya sebesar 74,12. Dengan demikian, dapat disimpulkan bahwa keterampilan berbahasa guru sekolah dasar di Kota Bandar Lampung dikategorikan baik.
\end{abstract}

Kata kunci : Keterampilan menulis, guru,

○2020 Jurusan Ilmu Pendidikan, FKIP Universitas Lampung

\section{PENDAHULUAN}

Terdapat sejumlah kebijakan yang menguatkan bahwa guru adalah pendidik profesional. Hal tersebut secara tegas dirumuskan dalam Undangundang RI Nomor 14 Tahun 2005 tentang Guru dan Dosen, Peraturan Pemerintah RI Nomor 19 Tahun 2005 tentang Standar Nasional Pendidikan, dan Peraturan Pemerintah RI Nomor 74 Tahun 2008. Guru yang dimaksud meliputi guru kelas, guru mata pelajaran, guru bimbingan dan konseling/ konselor, dan guru yang diangkat dalam jabatan pengawas satuan pendidikan.

Guru memegang peran yang sangat strategis dalam pembangunan suatu negara. Guru bukan hanya berperan sebagai pengajar dan pelatih tetapi 
terutama sebagai pendidik, dimana tidak hanya kemampuan intelektual saja yang harus dikembangkan tetapi juga kemampuan fisik yang berkaitan dengan kecekatan dan keterampilan (Robbins, 2001). Peran guru dapat ditunjukkan dengan berkreasi dalam pembelajaran dan dipublikasikan dengan keterampilan menulis yang baik (Setiawan, 2019). Dengan demikian, Guru dituntut untuk memiliki pengetahuan tentang konten (content knowledge) yang akan diajarkan dalam bentuk fakta, konsep, prinsip, hukum, dan teori, menguasai pengetahuan pedagogis (pedagogical knowledge) yang berkenaan dengan pengetahuan tentang merancang pembelajaran, metode pembelajaran, pengelolaan kelas, tujuan pendidikan, teori belajar, evaluasi pembelajaran, serta keterampilan pengaplikasikan pengetahuan pedagogik untuk mengajarkan pengetahuan konten (Shulman, 1986).

Sebagai hasilnya, setelah pendidikan di sekolah, siswa sudah memiliki kompetensi untuk melakukan satu pekerjaan tertentu atau untuk menghadapi satu situasi terentu (Spencer \& Spencer (1993). Selain itu, guru merupakan agen perubahan sosial yang mengubah pola pikir, sikap, dan perilaku umat manusia menuju kehidupan yang lebih baik, lebih bermartabat, dan lebih mandiri. Keberhasilan kinerja guru akan berdampak terhadap kualitas bangsa. Peran guru akan sangat berpengaruh terhadap terciptanya proses dan hasil pendidikan yang berkualitas, sehingga upaya perbaikan apapun yang dilakukan untuk meningkatkan kualitas pendidikan tidak akan memberikan sumbangan yang signifikan tanpa didukung oleh guru yang profesional.

Beragam upaya pemerintah untuk menjadikan guru sebagai pendidik professional, mulai dari pendidikan (pre-service) hingga sudah menjadi guru (in-service). Kebermutuan proses pendidikan guru menjadi upaya strategis dalam menyiapkan sumber daya manusia sebagai pelaku utama di era pesatnya perkembangan ilmu pengetahuan dan teknologi baik pada lingkup global maupun nasional. Sejumlah hasil penelitian membuktikan bahwa ada korelasi antara kompetensi guru tentang apa dan bagaimana siswa belajar dengan kondisi untuk belajar, dan keberhasilan guru dalam mengajar (Marton et al, 2014; Prosser \& Trigwell, 2008; Ramsden, 2012; Biggs, 2003). Indonesia merespon kondisi ini melalui kebijakan Undang-Undang Nomor 14 tahun Tahun 2005 tentang Guru dan Dosen yang secara langsung berimplikasi pada peran perluasan peran (wider mandat). Guru bukan hanya sebagai pengajar 
tetapi sebagai raw model dalam semua aspek perilaku yang dilihat dan didengar oleh anak.

Terdapat sejumlah tuntutan guru dalam mengemban amanah sebagai pendidik profesional. Hal ini tidak bisa dilepaskan dari keterampilan berbahasa, baik bahasa lisan maupun bahasa tulisan. Hal ini mempertimbangkan bahwa keterampilan berbahasa merupakan keterampilan berperan penting dalam pembelajaran (Pujiono, 2012). Dengan demikian, guru dituntut harus memiliki keterampilan berbahasa yang baik. Hal ini akan tergambar dari memilih bunyi-bunyi bahasa (berupa kata, kalimat, serta tekanan dan nada) secara tepat serta memformulasikannya secara tepat pula guna menyampaikan pikiran, perasaan, gagasan, fakta, perbuatan dalam suatu konteks komunikasi tertentu (Tarigan, 1986). Kemudian, guru dikatakan terampil mendengarkan (menyimak) apabila yang bersangkutan memiliki kemampuan menafsirkan makna dari bunyi-bunyi bahasa (berupa kata, kalimat, tekanan, dan nada) yang disampaikan pembicara dalam suatu konteks komunikasi tertentu (Anderson, 1972). Ketika keterampilan berbahasa guru rendah, maka tidak mustahil akan berdampak pada seluruh aspek perilaku anak baik kognitif, afektif maupun psikomotor.

Sebagai fasilitator dalam pembelajaran, keterampilan menulis harus dikuasai oleh guru (Sahidin \& Jamil, 2013). Hal mendasar yang membutuhkan keterampilan menulis yang baik adalah ketika guru menyusun baik proposal maupun laporan kegiatan. Dengan memiliki keterampilan menulis yang baik, proposal atau laporan tersebut dapat dipahami dan membuat pembaca percaya atas apa yang akan ataupun yang telah dilakukan. Guru dikatakan memiliki keterampilan menulis bila yang bersangkutan dapat memilih bentuk-bentuk bahasa tertulis (berupa kata, kalimat, paragraf) serta menggunakan retorika (organisasi tulisan) yang tepat guna mengutarakan pikiran, perasaan, gagasan, fakta. Terakhir, guru dikatakan terampil membaca bila yang bersangkutan dapat menafsirkan makna dan bentuk-bentuk bahasa tertulis (berupa kata, kalimat, paragraf, organisasi tulisan) yang dibacanya. Berdasarkan pada pandangan holistik tentang pembelajaran bahasa (Plakans \& Gebril, 2012), tugas menulis terintegrasi membutuhkan penggunaan keterampilan bahasa yang berbeda secara sinergis dan berbagai sumber. Ini menjadi perhatian yang 
besar dalam di dunia pendidikan dan penilaian bahasa (Cumming, Lai \& Cho, 2016; Plakans, Liao \& Wang, 2019; Yang \& Plakans, 2012).

Seiring dengan tuntutan Kurikulum 2013, maka tuntutan profesionalisme guru dalam keterampilan berbahasa menjadi sangat diutamakan karena kurikuum 2013 menekankan pendidikan secara konfluen dengan ciri-ciri utama 1) Partispasi; kurikulum ini menekankan partisipasi siswa dalam belajar. 2) Integrasi; adanya interaksi, interpenetrasi, dan integrasi dari pemikiran, perasaan dan juga tindakan. 3) Relevansi; adanya kesesuaian antara kebutuhan, minat dan kehidupan sasaran didik. 4) Pribadi anak; memberikan tempat utama pada pribadi anak untuk berkembang dan beraktualisasi potensi secara utuh. 5) Tujuan; memiliki tujuan mengembangka pribadi yang utuh. 6) evaluasi; lebih mengutamakan proses dari pada hasil. Intinya sasaran pendidikan ini dikemas dengan sikap spiritual dan sikap sosial yang diperoleh anak didik dari cara guru menjalin hubungan sosial baik secara akademik di dalam kelas maupun nonakademik dalam pergaulan sehari-hari.

Guru harus mampu menyuguhkan pembelajaran yang beretika bahasa yang baik. Landasan psikologis dari pembelajaran di SD adalah anak usia SD ini masih dalam rentangan berpikir integratif, yaitu berpikir dari hal umum ke bagian demi bagian, mereka memandang sesuatu yang dipelajari sebagai suatu keutuhan (holistik), belajar dari pengalaman nyata secara kontekstual (Piaget, 1972).

Persoalan ini harus menjadi kajian khusus di Lembaga Pendidikan dan Tenaga Kependidikan (LPTK) terutama yang berhubungan dengan keterampilan berbahasa pada lulusan Program Studi Pendidikan Guru Sekolah Dasar (PGSD) yang selama ini menjadi garda terdepan dalam menyiapkan tenaga guru untuk jenjang pendidikan SD. Program peningkatan profesionalitas guru akan berhasil jika diawali dengan analisis kemampuan guru. Oleh karena ini, penelitian ini bertujuan untuk mendeskripsikan keterampilan menulis guru di Kota Bandar Lampung.

\section{METODE}

Penelitian ini menggunakan pendekatan deskriptif analitik, yaitu untuk mengumpulkan informasi mengenai nilai keterampilan menulis guru (Arikunto, 2005) tanpa membuat perbandingan, atau menghubungkan dengan variabel 
yang lain (Sugiyono, 2008). Populasi penelitian ini dibatasi hanya guru sekolah dasar yang ada di Kota Bandar Lampung karena keterbatasan waktu untuk kemudian dilengkapi pada penelitian selanjutnya. Jumlah guru seluruhnya ada sekitar 2500 orang. Pertimbangan permasalahan yang akan diteliti memiliki kesamaan pada semua kecamatan, maka teknik pengambilan sampel dilakukan secara random. Setiap kecamatan diambil satu orang guru berarti akan diperoleh 26 guru yang mewakili 20 sekolah yang tersebar pada setiap kecamatan dan sudah menggunakan Kurikulum 2013 SD.

Metode pengumpulan data yang digunakan adalah angket dan dokumentasi portofolio. Kemudian, data yang terkumpul dianalisis secara statistik untuk kemudian dideskripsikan secara kualitatif. Untuk data yang bersifat kualitatif (deskriptif kualitatif), akan dikonversi dan dideskripsikan secara kuantitatif untuk kemudian dilakukan analisis statistik. Data deskriptif kualitatif dianalisis menurut isinya dan karenanya analisis seperti ini juga disebut analisis isi (content analysis). Dalam analisis deskriptif, data disajikan dalam bentuk tabel data yang berisi frekuensi, dan kemudian dianalisis sesuai dengan rancangan penelitian.

Keterampilan menulis guru dijabarkan menjadi 5 aspek penilaian, yaitu: isi, organisasi atau struktur teks, kosakata atau pilihan kata, penggunaan bahasa atau keefektifan kalimat dan mekanik atau tanda baca (Burhan, 2001). Aspek-aspek tersebut memiliki bobot masing-masing yang disesuaikan dengan tingkat kontribusi dalam menyusun karya tulis. Secara rinci, pembobotan setiap aspek penilaian dapat dilihat pada Tabel 1 .

Tabel 1. Aspek penilaian keterampilan menulis guru SD

\begin{tabular}{|c|c|c|c|c|c|}
\hline No & Aspek & Pernyataan Pemandu & $\begin{array}{l}\text { Rentang } \\
\text { Skor }\end{array}$ & Bobot & $\begin{array}{c}\text { Skor } \\
\text { Maksimal }\end{array}$ \\
\hline 1 & Isi & $\begin{array}{l}\text { Keterkaitan isi dengan topik, } \\
\text { lengkap, dan substantif. }\end{array}$ & $13-30$ & 1 & 30 \\
\hline 2 & $\begin{array}{c}\text { Organisasi/ Struktur } \\
\text { Teks }\end{array}$ & $\begin{array}{c}\text { Struktur teks penjelasan jelas, } \\
\text { padat, dan tertata dengan } \\
\text { baik. }\end{array}$ & $7-20$ & 1 & 20 \\
\hline 3 & $\begin{array}{c}\text { Kosakata/ Pilihan } \\
\text { Kata }\end{array}$ & $\begin{array}{c}\text { Pilihan kata yang digunakan } \\
\text { sesuai dengan situasi yang } \\
\text { diceritakan. }\end{array}$ & $7-20$ & 1 & 20 \\
\hline 4 & $\begin{array}{l}\text { Penggunaan Bahasa/ } \\
\text { Keefektifan Kalimat }\end{array}$ & $\begin{array}{c}\text { Bahasa yang digunakan } \\
\text { efektif dan konstruksi } \\
\text { kompleks. }\end{array}$ & $7-25$ & 1 & 25 \\
\hline \multirow[t]{2}{*}{5} & $\begin{array}{l}\text { Mekanik/ Tanda } \\
\text { Baca }\end{array}$ & $\begin{array}{l}\text { Penggunaan ejaan dan tanda } \\
\text { baca sudah tepat. }\end{array}$ & $2-5$ & 1 & 5 \\
\hline & & & Jumlah & & 100 \\
\hline
\end{tabular}


Indikator penilaian tersebut dijadikan pedoman untuk menentukan tingkat keterampilan menulis guru SD dimana data yang digunakan sebagai sumber penilaian adalah karya tulis guru yang berupa laporan Penelitian Tindakan Kelas (PTK). Laporan PTK yang digunakan pun sudah dibuat oleh guru sebelum penelitian ini dilakukan untuk meminimalisir tingkat kebiasan data.

Data yang diperoleh dan dianalisis kemudian dideskripsikan kembali ke data kualitatif untuk menentukan tingkat keterampilan berbahasa guru dengan mengikuti aturan yang disajikan dalam Tabel 2 di bawah ini.

Tabel 2. Kriteria Penilaian Ideal

\begin{tabular}{ccc}
\hline No & Rentang Skor & Kategori \\
\hline 1 & $\mathrm{x}>80$ & Sangat Baik \\
2 & $60<\mathrm{x}>=80$ & Baik \\
3 & $40<\mathrm{x}>=60$ & Cukup \\
4 & $20<\mathrm{x}>=40$ & Kurang \\
5 & $\mathrm{x}<20$ & Sangat Kurang \\
\hline
\end{tabular}

(diadaptasi dari Widoyoko, 2011).

\section{HASIL DAN PEMBAHASAN}

Berdasarkan data hasil penelitian, didapatkan skor rata-rata keterampilan menulis guru SD pada setiap aspek penilaian. Data tersebut disajikan pada Gambar 2 di bawah ini.

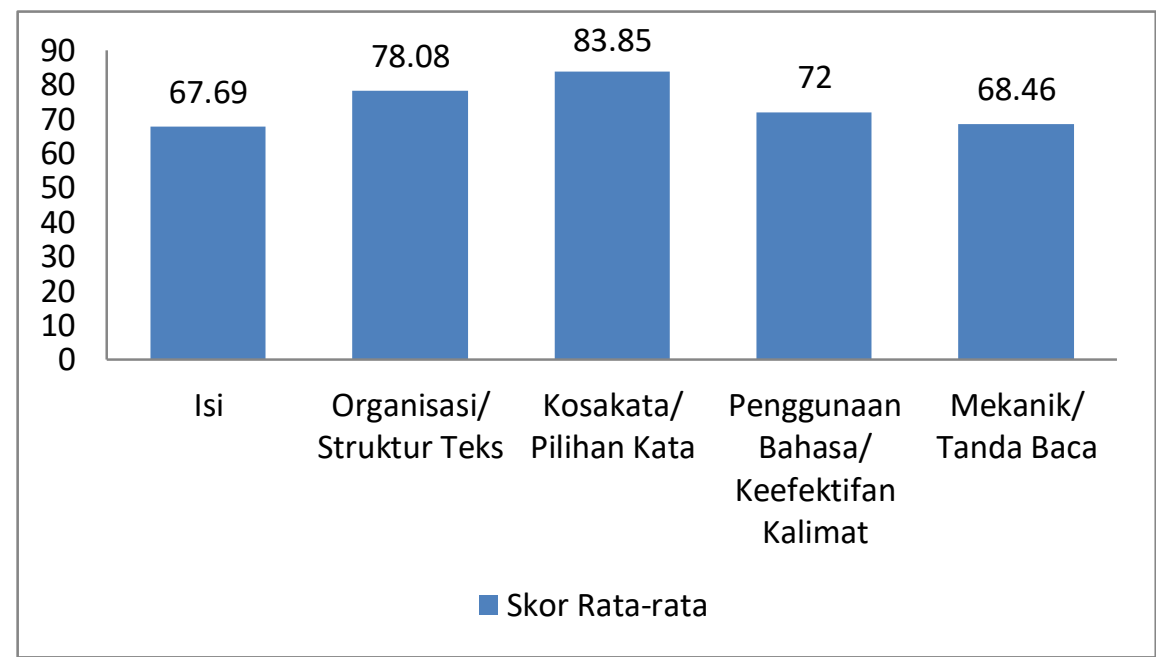

Gambar 2. Skor rata-rata keterampilan menulis guru SD pada setiap aspek penilaian. 
Berdasarkan data hasil penelitian, nilai rata-rata tertinggi terdapat pada aspek kosakata atau pilihan kata dengan skor 83.85 dan nilai rata-rata terendah terdapat pada aspek isi dengan skor 67.69. Hal ini menunjukkan bahwa guru memiliki kosakata yang dikategorikan sangat baik. Ini dipengaruhi dengan semakin canggihnya peralatan pendukung aktivitas guru di kehidupan sehari-hari yang memungkinkan terjadi transfer informasi berupa teks, suara ataupun kedua hal tersebut sekaligus. Informasi yang didapatkan dapat berupa kosakata baru yang dapat langsung dipahami dan digunakan sehingga menjadi tabungan kata dalam pikiran guru. Dengan demikian, ketika guru menyusun laporan penelitian ataupun pembelajaran dapat menuliskan kembali dalam kalimat yang tepat.

Namun, kemudahan dalam mendapatkan kosakata baru tidak diikuti dengan kualitasisi atau konten penulisan. Meskipun dengan skor 67.69 kualitas isi laporan PTK yang disusun oleh guru dikatakan baik akantetapi aspek ini berada pada nilai yang paling rendah dibandingkan dengan aspek lainnya. Hal ini menunjukkan bahwa guru memiliki kesulitan dalam memadukan topik penulisan baik antara kalimat satu dengan yang lainnya maupun antara paragraf satu dan lainnya. Ini terlihat dari minimnya kata penghubung antara kalimat atau paragraf satu dengan kalimat atau paragraf lainnya. Bahkan dalam satu kondisi, topik paragraf satu berbeda sekali dengan topik pada paragraf lainnya. Lebih jauh lagi, tidak ada kaitan antara kedua topik tersebut.

Selain itu, jika dipahami alur penulisan ide pokok cenderung zig-zag dan tidak sistematis. Ada satu waktu dimana ide pokok pada setiap paragraf berjalan mengulang. Contohnya, paragraf pertama sudah membicarakan pentingnya metode dan atau model pembelajaran, pada beberapa paragraf sesudahnya juga kembali menjelaskan hal tersebut dengan muatan yang sama. Ini terjadi mungkin karena guru mengutip tanpa proses parafrase dan mengulas kembali keseluruhan konten penulisan. Ini juga didukung dengan hasil penelitian terdahulu yang menyatakan bahwa guru sering memberikan tugas menulis awal yang seringkali difokuskan pada pembentukan huruf hafalan daripada kalimat yang lebih bermakna (Bingham, Quinn \& Gerde, 2017). Artinya, guru mungkin tidak benar-benar mampu untuk menuliskan kalimat kompleks yang kontekstual sehingga lebih mudah dipahami. Selain itu, 
Interaksi menulis guru dan siswa juga jarang terjadi (Zhang, Hur, Diamond \& Powell, 2015).

Pola pikir yang terputus-putus tersebut mungkin dipengaruhi oleh kemudahan dalam mendapat infomasi atau referensi penulisan di era Revolusi Industri 4.0 sehingga guru cenderung tidak percaya diri untuk menuliskan informasi berdasarkan kemampuan sendiri. Guru beranggapan bahwa apa yang didapatkan dari media berbasis TIK selalu ter-update dan terbaik. Padahal jika dipahami secara mendalam, pendapat guru sendiri tidak kalah baik dengan yang didapatkan baik dari artikel ataupun referensi lainnya.

Data yang sama dapat dikonversi dan disajikan dalam bentuk seperti Gambar 3 untuk mengetahui responden yang memiliki skor tertinggi dan terendah pada setiap aspek.

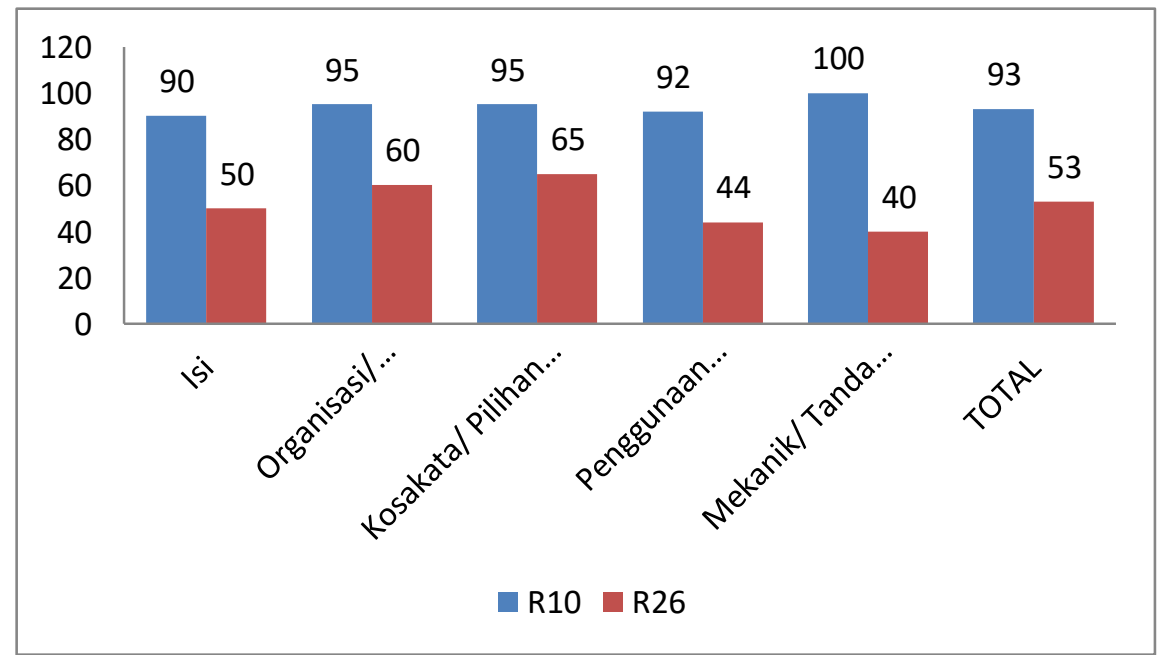

Gambar 3. Skor tertinggi dan terendah keterampilan menulis guru SD

Data skor total semua responden dapat ditunjukkan pada Gambar 4 di bawah ini. Dengan demikian, sebaran skor seluruh responden dapat diketahui. 


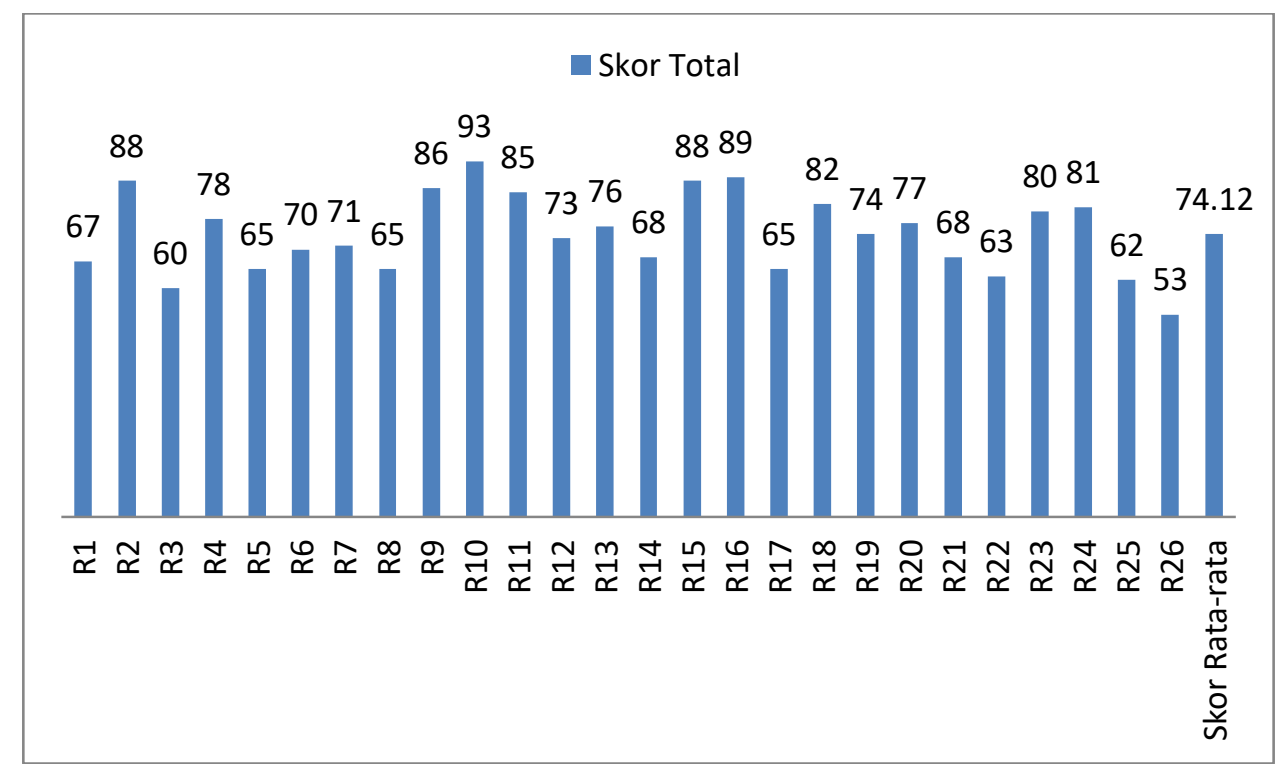

Gambar 4. Skor keterampilan menulis guru SD

Berdasarkan Gambar 4, dapat dinyatakan bahwa skor rata-rata responden sebesar 74.12. Jika skor rata-rata tersebut dijadikan satu batas, maka terdapat 14 responden yang skornya di bawah skor rata-rata dan sisanya, sebanyak 12 responden; berada di atas skor rata-rata sampel.

Di lain pihak, keterampilan antara guru satu dan lainnya memiliki kesenjangan yang cukup signifikan. Ini terlihat dari perbandingan skor tertinggi dan skor terendah, yaitu: secara berturut-turut 93 dan 53. Keunikan yang terjadi adalah skor terendah dan tertinggi terdapat pada aspek mekanik atau tanda baca dimana skor tertinggi adalah 100 dan skor terendah adalah 40 . Ini menunjukkan bahwa tidak semua guru memahami tanda baca dalam penulisan laporan atau karya ilmiah. Meskipun demikian, perlu dipahami bahwa usia responden yang mendapat skor terendah dapat dikatakan sudah terlampau senior yang mana pada masa pendidikan untuk menyelesaikan tugas akhir belum menggunakan alat secanggih sekarang ini (masih menggunakan mesin tik) sehingga ketika sekarang ini dianjurkan untuk menggunakan $M_{S}$. Word dalam pengolahan kata, guru tidak terlalu terampil mengoperasikan meskipun secara teori memahami tanda baca. Ini berbeda sekali dengan responden yang mendapatkan skor tertinggi dimana usia masih terbilang muda dan aktif mengikuti perkembangan produk hasil teknologi yang mendukung aktivitas akademik. 
Secara keseluruhan, nilai rata-rata keterampilan guru SD di Kota Bandar Lampung dikategorikan baik dengan skor rata-rata 74.12, dimana skor 12 responden berada di atas skor rata-rata dan 14 responden memperoleh skor di bawah rata-rata. Ini menunjukkan bahwa perlu ada peningkatan kemampuan guru dalam menulis. Apalagi, masih banyak guru yang enggan untuk menuangkan hasil pemikirannya dalam bentuk tulisan (Sauri, 2010) untuk dipublikasikan dalam bentuk artikel. Padahal ketika guru dapat mempublikasikan ide-ide kreatifnya, maka ini dapat menginspirasi guru-guru lain untuk dapat meniru dan pada akhirnya dapat mengembangkan pembelajaran-pembelajaran inovatif lainnya.

Level keterampilan tersebut perlu ditingkatkan untuk menjadi guru professional. Peningkatan ini dapat dilakukan melaui pelatihan dan pendampingan menulis karya ilmiah berdasarkan kegiatan pembelajaran berbasis kearifan lokal. Ini akan mempermudah guru-guru untuk menuangkan dalam bentuk kata-kata karena didasari oleh kegiatan-kegiatan yang sering mereka lakukan dalam pembelajaran.

Meskipun demikian, saran teknis dalam menulis, walaupun bermanfaat; masih belum cukup untuk membangun kebiasaan produktif dalam menulis di kalangan akademisi (Moore, 2003; Murray, 2013).

Proses menulis ini dapat dilakukan setiap hari secara rutin sampai tersusun draft artikel ilmiah. Kegiatan ini seperti memasukkan pengajaran bahasa berdasarkan data penelitian ke dalam kegiatan membaca buku bersama (mis., McGee \& Schickedanz 2007; Piasta, Dynia, Justice, Pentimonti, Kaderavek \& Schatschneider, 2010).

Selanjutnya, guru dapat mempublikasikan hasil karya tulis ilmiah tersebut. Karya ilmiah atau artikel dan publikasinya adalah satu kesatuan yang penting sebagai bentuk aktualisasi guru dalam menjalankan tugas professional (Supriyanto, 2017). Dalam kasus publikasi, guru juga perlu mendapatkan pelatihan. Ini mempertimbangkan bahwa kinerja guru dalam mempublikasikan karya ilmiah belum optimal (Ahmadi, Widihastrini \& Widhanarto, 2019) Lebih jauh lagi, guru juga perlu mendapatkan pelatihan untuk meningkatkan literasi teknologi. Ini mempertimbangkan bahwa segala 
aktivitas kehidupan ini sekarang ini perlu menyesuaikan dengan perkembangan Iptek.

Namun, beberapa peneliti menyarankan bahwa guru harus membuat kegiatan menulis secara rutin (mis., Wasik \& Hindman 2011; Gerde, Bingham \& Wasik, 2012). Oleh karena itu, lingkungan di sekolah harus dikondisikan agar para guru dapat membiasakan diri untuk menulis baik untuk keperluan publikasi maupun laporan-laporan kegiatan. Ini sesuai dengan hasil penelitian yang dilakukan oleh Kramer \& Libhaber (2016) yang menyatakan bahwa lingkungan yang memungkinkan dapat memfasilitasi pengembangan keterampilan menulis. Lingkungan ini dapat dimulai dengan menghimbau para guru untuk melaporkan hal-hal yang terjadi selama pembelajaran di kelas dalam bentuk tulisan. Ini untuk menumbuhkan kepercayaan diri guru bahwa menulis itu dapat dimulai dari hal-hal kecil yang terjadi di sekitarnya. Apalagi, hasil penelitian menunjukkan bahwa kurangnya kepercayaan diri juga menjadi hambatan dalam menulis (Ness, Duffy, McCallun \& Price, 2013). Ini perlu dilakukan secara terus-menerus setiap periode mempertimbangkan bahwa waktu yang terputus juga berdampak negatif bagi guru dalam menulis (Jackson, 2008).

\section{KESIMPULAN}

Berdasarkan pembahasan yang telah diuraikan, maka dapat disimpulkan bahwa keterampilan menulis guru sekolah dasar di Kota Bandar Lampung dikategorikan baik. Meskipun demikian, perlu adanya peningkatan literasi teknologi guru sebagai kebutuhan dasar di era digital agar pengetahuan menulis yang baik dapat diterapkan dalam media digital.

\section{DAFTAR PUSTAKA}

Ahmadi, F., Widihastrini, F., \& Widhanarto, G. P. (2019). Ibm Guru Sekolah Dasar Melalui Pelatihan Peningkatan Keterampilan Menulis Artikel Penelitian Tindakan Kelas. Jurnal Abdimas, 22(2), 137-142.

Anderson, R. C. 1972. Language Skills in Elementary Education. NewYork: Macmillan Publishing Co, Inc.

Arikunto, Suharsimi. (2005). Manajemen Penelitian. Jakarta: Rineka Cipta. 
Biggs, J.B. (2003). Teaching for Quality Learning at University, 2nd Ed., The Society for Research into Higher Education \& Open University Press, Buckingham.

Bingham, G. E., Quinn, M. F., \& Gerde, H. K. (2017). Examining early childhood teachers' writing practices: Associations between pedagogical supports and children's writing skills. Early Childhood Research Quarterly, 39, 35-46.

Burhan, N. (2001). Penilaian dalam Pengajaran Bahasa dan Sastra. BPFE, Yogyakarta.

Cumming, A., Lai, C., \& Cho, H. (2016). Students' writing from sources for academic purposes: A synthesis of recent research. Journal of English for Academic Purposes, 23, 47-58. https:// doi.org/10.1016/j.jeap.2016.06.002.

Gerde, H. K., Bingham, G. E., \& Wasik, B. A. (2012). Writing in early childhood classrooms: Guidance for best practices. Early Childhood Education Journal, 40(6), 351-359.

Jackson, D. (2008). Servant leadership in nursing: a framework for developing sustainable research capacity in nursing. Collegian. 15, 27-33.

Kramer, B., \& Libhaber, E. (2016). Writing for publication: institutional support provides an enabling environment. BMC Medical Education, 16(1), 1-5.

Marton, F., \& Saljo, R. (2014). Approaches to learning. The experience of learning. Implications for teaching and studying in higher education (pp. 39-58). Edinburgh: Scottish Academic Press.

McGee, L. M., \& Schickedanz, J. A. (2007). Repeated interactive read-alouds in preschool and kindergarten. The Reading Teacher, 60(8), 742-751.

Moore, M. (2003). Writers' Retreats for Academics: Exploring and Increasing the Motivation to Write. Journal of Further and Higher Education 27(3), 333-343

Murray, R. (2013). Writing for A cademic Journals. Maidenhead and New York: Open University Press.

Ness V, Duffy K, McCallum J \& Price, L. (2013). Getting published: Reflections of a collaborative writing group. Nurse Educ Today. http://dx.doi.org/10.1016/j.nedt.2013.03.019.

Piaget, J. (1972). The child and reality, problems of genetic psychology. New York: Penguin Books. 
Piasta, S. B., Dynia, J. M., Justice, L. M., Pentimonti, J. M., Kaderavek, J. N., \& Schatschneider, C. (2010). Impact of professional development on preschool teachers' print references during shared read alouds: A latent growth curve analysis. Journal of Research on Educational Effectiveness, 3(4), $343-380$.

Plakans, L., \& Gebril, A. (2012). A close investigation into source use in integrated second language writing tasks. Assessing Writing, 17(1), 18-34. https://doi.org/10.1016/j.asw.2011.09.002.

Plakans, L., Liao, J.-T., \& Wang, F. (2019). "I should summarize this whole paragraph": Shared processes of reading and writing in iterative integrated assessment tasks. Assessing Writing, 40, 14-26. https://doi.org/10.1016/j.asw.2019.03.003.

Prosser, M. and Trigwell, K,(2008). Teaching for learning in higher education.

Pujiono, S. (2012). Berpikir Kritis dalam Literasi Membaca dan Menulis untuk Memperkuat Jati Diri Bangsa. Prosiding PIBSI XXXIV, 778-783.

Ramsden, P. (2012), Learning to Teach in Higher Education. London: Routledge.

Robbins, Stephen P. (2001). Perilaku Organisasi: Konsep, Kontroversi, Aplikasi, Jilid 1, Edisi 8. Prenhallindo: Jakarta.

Sahidin, L., \& Jamil, D. (2013). Pengaruh Motivasi Berprestasi dan Persepsi Siswa tentang Cara Guru Mengajar terhadap Hasil Belajar Matematika. Jurnal Pendidikan Matematika, 4(2), 212-222.

Sauri, S. (2010). Membangun Karakter Bangsa Melalui Pembinaan Pofesionalisme Guru Berbasis Pendidikan Nilai. Jurnal Pendidikan Karakter, 2(2), 1-15.

Setiawan, A. (2019, November). Peran keterampilan menulis dalam meningkatkan profesionalitas guru di era society 5.0. In Prosiding Seminar Nasional Bahasa dan Sastra Indonesia (SENASBASA) (Vol. 3, No. 2).

Shulman, L.S. (1986). Those who understand: Knowledge growth in teaching. Educational. Educational Researcher, 15(2), 4-14.

Spencer, Lyle M., Jr. \& Signe M., Spencer. (1993). Competence at Work: Models for Superior Performance. John Wiley \& Sons. Inc.

Sugiyono. (2008). Metode Penelitian Kunatitatif Kualitatif dan R \& D. Bandung: Alfabeta. 
Supriyanto, A. 2017. Peningkatan Kemampuan Guru Dalam Penulisan Karya Ilmiah Melalui Pelatihan Penelitian Tindakan Kelas. Jurnal Abdimas Pedagogi,1 (1): 1-7.

Tarigan, Henry Guntur. (1986). Menyimak sebagai Suatu Keterampilan Berbahasa. Bandung: Angkasa.

Wasik, B. A., \& Hindman, A. H. (2011). The morning message in early childhood classrooms: Guidelines for best practices. Early Childhood Education Journal, 39(3), 183-189.

Widoyoko, E. P. (2011). Teknik Penyusunan Instrumen Penelitian. Yogyakarta: Pustaka Pelajar.

Yang, H.-C., \& Plakans, L. (2012). Second language writers' strategy use and performance on an integrated reading-listening-writing task. TESOL Quarterly, 46(1), 80-103. https://doi.org/10.1002/ tesq.6

Zhang, C., Hur, J., Diamond, K. E., \& Powell, D. (2015). Classroom writing environments and children's early writing skills: An observational study in Head Start classrooms. Early Childhood Education Journal, 43, 307-315. 